\title{
Management of Pests and Pathogens Affecting Citrus Yield in Egypt with Special Emphasis on Nematodes
}

\author{
Mostafa M.A. Hammam1, Mahfouz M.M. Abd-Elgawad', Weibin Ruan ${ }^{2}$ \\ and Ahmed El-bahrawy ${ }^{3}$
}

\begin{abstract}
${ }^{1}$ Plant Pathology Dept., National Research Centre, Dokki, Giza, Egypt; ${ }^{2}$ College Life Science, Nankai Univ., Tianjin 30071, China; ${ }^{3}$ Inst.Sustainable Plant Prot., National Council Research, Bari, Italy.

Corresponding author email: mahfouzian2000@yahoo.com
\end{abstract}

\begin{abstract}
Although citriculture ranks high in Egypt as a superior orange producer and exporter country, citrus yield should be further optimized via management of pests and pathogens that adversely affect citrus orchards. We throw light on the various groups of these citrus-damaging organisms to alarm for the significance of adopting adequate programs for their control. As many plant-parasitic nematode (PPN) species in Egypt and abroad; all but one, the citrus nematode Tylenchulus semipenetrans, of which are of limited distribution, this species was addressed herein in details. The citrus nematode could significantly reduce lemon yield. Before nematicidal application, growers and stakeholders should adopt strict quarantine and seedling certification programs, consider the limiting factor principle, and use appropriate nematode sampling and extraction methods. Moreover, bionematicides should be earnestly tried among other PPN management options in order to avoid human health hazards and attain pollution-free environment. Yet, holistic management should include not only nematodes but also other pests and pathogens of citrus in Egypt. We highlighted general production practices that should adequately tackle relevant citrus problems.
\end{abstract}

Keywords: Citrus pests and pathogens, Nematode management, Production practices, Yield loss.

\section{INTRODUCTION}

Citriculture ranks high in Egypt which holds the first/second largest exporter of fresh oranges in the world and the sixth largest orange producer for years (Omar and Tate 2018). In marketing year (MY) 2020/21, Foreign Agricultural Service (FAS) of the United States Department of Agriculture (USDA) in Cairo forecasts fresh orange exports to reach 1.5 million metric tons (MMT) up from 1.37 MMT in MY 2019/20. The Egyptian superiority in exporting citrus fruits is due to the growth of local production, with a commitment to applying international standards of export quality, from cultivation to packaging and export. Moreover, the forefront of Egypt in the global market is supported by the decision to liberalize its currency exchange rate, which gives it a great competitive price advantage. On the other hand, the continuous nature of the economic crisis associated with COVID 19 is expected to enhance the socioeconomic significance of citrus; citriculture grants an important source of foreign currency in Egypt in addition to attractive citrus local consumption, e.g. as 
fresh fruit and juice. Citriculture alleviates the striking problem of unemployment in Egypt. Many orchards-owning families join to work due to the frequently small orchard size in Egypt and labor-intensive nature of citriculture. So, there is a continuous expansion in citriculture to newly reclaimed areas of Egypt. For example, in 2018/2019, FAS (USDA), forecast total planted area in oranges at 162,000 ha, a $5.1 \%$ increase from the previous year (Omar and Tate, 2018). Yet, in MY 2020/21, FAS (USDA) reported total planted area in oranges at 168,000 hectares (ha), almost similar to the previous marketing year (Wally and Akingbe, 2020). The increase in planted area is attributed to increased demand for the Egyptian citrus in the local and international markets. Most of the area planted with oranges is located in reclaimed lands which account for 60 percent of the total area. Plantations in the Nile Delta region account for 40 percent of the total orange planted area. Thus, the increase in the planted area also contributes to solve the present pressing problem of overpopulation by resettling people in such new areas.

Notwithstanding the current position for high Egyptian citrus export, a number of recent, high-profile, scientific trends and policy makers have identified the need for a holistic approach to face a broad range of citrus issues. Similarly, other countries as China have begun to make dynamic changes in pest management targeting modernization. Non-chemical management (green control) in China currently includes agricultural control such as cultural measures, sanitation of winter orchards, trunk paint, pruning, citrus orchards ground cover, biological control via conservation of natural enemies and artificial mass rearing and release of natural enemies, and mineral pesticides. Also, China apply safe control methods as sex pheromone, food baits, and physical and mechanical control techniques, e.g. light trap, yellow sticky trap, and fruit bagging (Raza et al., 2017). Yet, there is still a long way to go in all major aspects relevant to citrus insect pest management. No sustainable crop protection strategies will be successful in the long-term agriculture if the soil health and fertility as well as proper irrigation water in terms of its quality and quantity are not neatly considered within the frame of integrated pest management (IPM) programs. For Egyptian citrus, these topics mainly address soil conservation, water availability, and the need for sustainable and improved production practices, to name a few, for pest and pathogen management.

\section{Factors Affecting Citrus Yield in Egypt}

\section{A) Pests and Pathogens of Citrus}

Insect pests of Egyptian citrus are many harmful species and may comprise the citrus leafminer, Phyllocnistis citrella Stainton, aphids, Aphis spp., scale insects such as red scale (Aonidiella aurantii Maskell), black scale (Saissetia oleae Olivier), purple scale (Lepidosaphes beckii Newman), black parlatoria scale (Parlatoria ziziphi Lucas), brown soft scale (Coccus hesperidum L.), Florida wax scale (Ceroplastes floridensis Comstock), and citricola scale (Coccus pseudomagnoliarum Kuwana) insects, citrus mealybug (Planococcus citri Risso), cottony cushion scale (Icerya purchasi Maskell), Mediterranean fruit fly or Medfly (Ceratitis capitata Wiedemann), citrus whitefly (Dialeurodes citri Ashmead), citrus flower moth (Prays citri Meyrick), green stink bug (Nezara viridula L.), hairy rose beetle, (Tropinota squalida Scop.), the honeydew moth or Christmasberry moth (Cryptoblabes gnidiella Millière), and citrus thrips (Scirtothrips citri Moulton). In addition, many non-insect pests can harm citrus trees including mites, plant-parasitic nematodes (PPNs), snails, rats and bats (Ibrahim and Khaleef, 1997). Various mite pests may include the citrus rust mite (Phyllocoptruta 
oleivora Ashmead), citrus bud mite (Aceria sheldoni Ewing), citrus flat mites (Brevipalpus californicus Banks, B. obovatus Donnadieu, B. phoenicis Geijskes), and citrus red mite (Panonychus citri McGregor). Although many plant-parasitic nematodes are found in Egyptian citrus orchards, the citrus nematode (Tylenchulus semipenetrans) is the most spread and consequently is considered the most economically important species (Abd-Elgawad 2020a). In Egyptian orchards, the following PPN genera (with related species) are associated with citrus tree roots: the lesion nematode Pratylenchus ( $P$. brachyurus, $P$. coffeae, $P$. neglectus, $P$. penetrans, $P$. pratensis, $P$. vulnus, $P$. zeae), the stunt nematode Tylenchorhynchus (T. besselatus, $T$. brassicae, $T$. clavicaudatus, $T$. latus, $T$. nothus, $T$. phaseoli), the lance nematode Hoplolaimus $(H$. columbus, $H$. galeatus, $H$. seshadrii), the spiral nematode Helicotylenchus (H. dihstera, $H$. hydrophilus, $H$. microcephalus, $H$. multicinctus, $H$. pseudorobustus), the sheath nematode Hemicycliophora (H. Arenaria, H. similis), the needle nematode Longidorus (L. africanus, L. alongates, L. gerogiensis, L. taniwha), the burrowing nematode Radopholus ( $R$. similis, $R$. citri), the stubby root nematode Trichodorus (T. teres, T. christie), the dagger nematode Xiphinema (X. imitator, X. insigne, X. lamberti), and the reniform nematode Rotylenchulus reniformis (Ibrahim, 2006). For instance, PPNs found in the citrus soil and the average percentages of the total nematode community in an Egyptian survey were T. semipenetrans (81.2\%), Helicotylenchus pseudorobustus (11.7\%), Criconemella spp. (6.5\%), Pratylenchus brachyurus $(0.2 \%)$ and Tylenchorhynchus spp. (0.4\%) in Northern Tahrir Province (Abd-Elgawad 1992a). Other than Tylenchulus semipenetrans (99.1\%), the genera Tylenchorhynchus, Helicotylenchus, Criconemoides, Xiphinema and Pratylenchus total $0.9 \%$ of the whole nematode community in citrus groves of El-Nubaria district, El-Behera governorate (Abd-Elgawad et al., 2016). Additional genera such as Meloidogyne (root-knot nematode, RKN) and Longidorus were found in citrus orchards intercropped with tomato in the New Valley governorate (Abd-Elgawad, 2020a). Therefore, a consensus has been reached on the need for an integrated pest management (IPM) approach (Ali et al., 2020).

\section{B) Other Factors Affecting Citrus Yield}

As it is clear from the above account, the pests and pathogens of citrus groves in Egypt are many and varied with other abiotic factors that can impose additional damages. The most significant abiotic factors are unfavorable weather conditions in Egypt, e.g. high temperatures and/or severe winds during flowering or/and early fruit set. In these events, flowers and small fruits may often dramatically fall which leads to a lack of yield. This is especially important in February, March, April, May, and June. In addition, the complex network of interactions among biotic and abiotic factors in intimate contact with these pests and pathogens should be further researched to understand their merits and demerits in the tree rhizosphere. For instance, boosting natural enemies associated with some economic pests of citrus in Egyptian agroecosystems should be sought (e.g., El-Husseini et al., 2018). Therefore, agricultural and production practices in citrus orchards should be relied upon, with special attention to each orchard separately, according to the problems it faces, especially those that can limit its current or future productivity. These practices are critical factors in promoting citrus production. 


\section{Plant-Parasitic Nematodes of Citrus in Egypt}

Due to the above-mentioned huge numbers and many species of pests and pathogens of Egyptian citrus, the following part will focus on an important group of these pests, the plant-parasitic nematodes. Factually, PPNs and entomopathogenic nematodes (EPNs) are two important sets as harmful and beneficial organisms, respectively in crop production systems (Abd-Elgawad, 2021b). In this respect, the proportion of nematode injury to any plant species is also related to PPN species/race, densities, and existing conditions, abiotic and biotic factors. For instance, $T$. semipenetrans ranks high due to its spread and prevalence relative to other phytonematodes on citrus in Egypt (Abd-Elgawad, 1992b; Korayem and Hassabo, 2005; Hammam et al., 2016; Abd-Elgawad et al., 2016). Hence, we focus on the importance of the citrus nematode, Tylenchulus semipenetrans. Effective control methods of the most common and harming PPNs related to citrus trees within the frame of general management strategies of citrus orchards to maximize citrus yield and quality in Egypt are addressed.

\section{A. Tylenchulus semipenetrans}

\section{i) Its Distribution and Significance}

The citrus nematode is not only a parasite of more than 75 rutaceous species as suitable hosts (Duncan, 2009) but has also non-rutaceous hosts, e.g. grape, olive, persimmon and lilac (Abd-Elgawad, 2020a). As a prevailing PPN pest, it formed 81.2\% (Abd-Elgawad, 1992a) and 99.1\% (Abd-Elgawad et al., 2016) of the whole nematode population in surveys conducted in two zones known for growing citrus in Egypt. In contrast, non-Egyptian surveys revealed that $T$. semipenetrans infested 70$90 \%$ of commercial citrus orchards in Brazil and Spain but less than that (24-60\%) in Florida and California, USA (Shokoohi and Duncan, 2018). Such widespread infestations tattle that it can damage citrus produce under a broad range of ecological and edaphic conditions. This nematode causes 'the low decline disease of citrus' as a gradual tree weakness is usually associated with the nematode infection, parasitism, and reproduction on the tree roots. Therefore, the disease symptoms are comparable to those induced by nutrition deficiency, drought, or poor root development. However, the infected trees can usually back high $T$. semipenetrans population levels even before the tree damage is significant especially for producing, not young, trees. Leaves and fruit become sub-size and chlorosis may be obvious. Symptom evolution and disease progress rely on overall orchard conditions. Root hairs are decayed and/or less abundant leading to wilting especially during periods of water stress and leaf drop is more severe resulting in thinner tree canopies in sharply $T$. semipenetrans-infected trees. On the contrary, infected trees growing under favorable conditions may yield somewhat fewer numbers of fruits while looking quite healthy (Duncan, 2009). Under disadvantageous conditions for tree development, the $T$. semipenetrans impacts are so evident; leaf drop is more frequently occurred, leading to twig dieback (exposed branch terminals). Moreover, excessive sodium accumulates in leaves under saline conditions (Mashela and Nthangeni, 2002). Feeder roots are somewhat thicker than healthy ones but with a dirty look due to adhering soil particles to gelatinous $T$. semipenetrans-egg masses on the surface of heavily-infected roots. Conversely, these manifestations may not be clear on roots with non-heavily or light $T$. semipenetrans infections. Therefore, T. semipenetrans-infected seedlings may easily go undetected on getting them from nurseries. Nonetheless, infected roots decay more rapidly resulting in invasion by other pathogens such as bacteria and fungi. This may manifest 
root lesions in light infection, but heavy infections usually result in cortical sloughing and eventually root death. Nematode infection enhances levels of the cell-damaging enzymes (Abd-Elgawad et al., 2015).

\section{ii) Its Biology and Ecology}

The citrus nematode biology and ecology have been thoroughly reviewed (Shokoohi and Duncan, 2018). The egg hatches to filiform second stage juvenile (J2) which does not immediately penetrate the roots. Tylenchulus semipenetrans is sexually dimorphic with males having the ability mature to the filiform adults without feeding. The female juveniles can survive more than two years in the absence of roots (Duncan, 2009). Amphimictic females can produce male and female offspring without mating. The juveniles feed for up to two weeks on roots' epidermal cells then molt in about seven days to the third, fourth and adult females. The anterior of young females penetrate deep into the fibrous root cortex to induce a permanent feeding site and grow to turn into swollen females. They parasitize routinely on several nurse cells which frame $T$. semipenetrans heads but their posteriors stay exposed on the roots. Nearly six weeks after egg hatching at $25^{\circ} \mathrm{C}$, females lay eggs on the root surface in a gelatinous egg mass secreted from the excretory pore.

Duncan (2009) contemplated a close coevolution of T. semipenetrans with citrus and other deep-rooted trees as this nematode can stimulate a complicated set of nurse cells in the cortex of the infected host roots. Although $T$. semipenetrans can obtain nutrients via nurse cells, this usually induces slight damage to the host. As a result, the host roots can boost large nematode numbers for years. The nematode population densities are impacted differently in response to various edaphic and environmental factors such as natural enemies, temperature, and soil moisture. Thus, it is not weird that one (Sorribas et al., 2000), two (Salem, 1980), or three (Abd-Elgawad et al., 1994) distinct peaks in terms of active T. semipenetrans population development per year are reported. Interestingly, no seasonality was also found (Cohn, 1966). The fastest growth of $T$. semipenetrans occurred at $25^{\circ} \mathrm{C}$ with but slow developing rates are reported as temperatures neared upper $\left(31^{\circ} \mathrm{C}\right)$ and lower $\left(20^{\circ} \mathrm{C}\right)$ limits for population growth (O'Bannon et al., 1966). High summer soil temperatures may be associated with seasonally low populations in Egypt (Salem 1980). The citrus nematode has little tolerance for desiccation survival (Tsai and Van Gundy, 1988). However, soil moisture is often inversely related to $T$. semipenetrans population growth (Sorribas et al., 2000). Whether part or all of the root system is influenced by drought, $T$. semipenetrans populations can either grow very fast or decline precipitously (Duncan,2009). Their population levels are higher under drip than under flood irrigation (Sorribas et al., 2000). Clearly, the population fluctuation of the nematode is adjusted by seasonal growth of tree organs and the availability of nutrients in roots. New/seasonal roots are convenient for $T$. semipenetrans penetration, development and reproduction. Heavy infection can harm and decompose substantial feeder root masses. Therefore, slightly $T$. semipenetrans-infected trees possess more rooted mass than heavily infected trees. This may result in erratic estimate via relating yield loss to nematode numbers if novel root growth is still not found to substitute those damaged by $T$. semipenetrans during sampling. Salinity and $\mathrm{pH}$ of soil can affect $T$. semipenetrans differently (Shokoohi and Duncan, 2018). The nematode harm to citrus occurs at $\mathrm{pH} \mathrm{6-8} \mathrm{but} \mathrm{it} \mathrm{is} \mathrm{greater} \mathrm{in} \mathrm{mild} \mathrm{alkaline} \mathrm{calcareous}$ soil than in highly acidic soils. Also, the magnitude of tree nutrition influences population levels (Mangat and Sharma, 1981). The genetic constitution of rootstock 
impacts T. semipenetrans population growth which varies among resistant rootstocks (O’Bannon and Hutchinson, 1974).

In the stable habitat, the citrus rhizosphere often possesses a varied assortment of many microorganisms worldwide (Shokoohi and Duncan, 2018). In Egypt, production practices, e.g. adding humic acid can boost available nutrients and consequently microbial activity to increase citrus production (Ennab, 2016). However, $T$. semipenetrans interacts differently with the associated fauna and flora according to the interacted species. For instance, T. semipenetrans infection to citrus seedlings can alleviate the following infection of roots by Phytophthora nicotianae, but it can elevate the virulence of Fusarium solani (Shokoohi and Duncan, 2018). Also, high population density of $T$. semipenetrans shows synergistic effect with $F$. semitectum on harming the seedlings (Safdar et al., 2013).

\section{iii) Diagnosis of $T$. semipenetrans}

Adequate nematode sampling and extraction protocols and methods should be followed to avert misleading data (Abd-Elgawad, 2021b). Often, nematodes are aggregated in soil and citrus roots. So, sample size can be decreased but with the same accuracy level by sampling during seasons of high $T$. semipenetrans population density and in locations of abundant feeder root for its feeding. Also, stratified sampling of orchards into strata of healthy and unhealthy trees may boost sample precision. Nonetheless, logical sampling for comparison is conducted in the same season each year especially at the highest expected $T$. semipenetrans densities. Tree roots and $T$. semipenetrans are more abundant under the tree canopy than at the dripline or in rows between trees (Duncan, 1986). Low-volume irrigation networks condense root and nematode population densities just in the moistened areas (Shokoohi and Duncan, 2018).

Nematode sample size with accurate assessment of $T$. semipenetrans density is generally expensive (Abd-Elgawad, 2017c). Luckily, sampling even with relatively low precision is often worthy since the majority of $T$. semipenetrans population densities are well above or below management threshold levels (Shokoohi and Duncan, 2018). Moreover, enhancing optimum size of nematode samples via iteration is recommended (Abd-Elgawad, 2016). It may be followed to derive a more proper value of the statistical variable $t$ instead of, 2 , its assumed imprecise estimate. In this respect, comparing precision for three different sampling schemes concerning estimates of $T$. semipenetrans population level on citrus in Egypt and Florida are presented (Table 1). For each scheme, confidence profiles at three probability levels and standard error to mean ratios are assessed via the published parameters of Taylor Power Law related to the schemes. The confidence intervals around the means of $T$. semipenetrans figures are typically broad for 99\%, 95\%, and $80 \%$ probability standards compared to Meloidogyne spp. This is probably due to the high counts of $T$. semipenetrans population utilized and the relatively low number of obtained samples. Yet, Florida populations of $T$. semipenetrans indicated narrower confidence bands than those of stratified random. This latter in turn had limited confidence bands compared to systematic sampling method in Egypt (Abd-Elgawad, 2020a).

\section{iv) Its Effect on Citrus Yields}

Assessing citrus yield loss relies on relating either natural nematode infestation densities or nematode population levels following nematicidal application to yield parameters. Both cases have restrictions. For instance, nematicides may affect not only $T$. semipenetrans populations but also other rhizosphere organisms such as 
natural enemies and fungal and/or bacterial pathogens. Moreover, nematicidal application may also directly affect plant development adversely (Timmer, 1977) or favorably (Wheaton et al., 1985). Otherwise, edaphic factors can differently impact either T. semipenetrans populations, trees, or both of them. Moreover, as citriculture usually manifests perennial trees, this relationship is occasionally distorted and/or falsified by cyclic $T$. semipenetrans population development, carry-over stress impacts from one crop/year to the next, the interaction between nematode and other stresses and by the status of vigorous trees to back (tolerate) higher T. semipenetrans population densities than trees in decline (Abd-Elgawad et al., 2016). Yet, a few models for relating yield to nematode infestation levels evidenced significant citrus yield loss due to the citrus nematode. For instance, yield loss of lemon in Egypt was estimated (Table 2) and averaged $28.7 \%(\mathrm{P}=0.026)$. This assessment related tree yield to natural $T$. semipenetrans infestation density. Nevertheless, it is logic to assume that the differences in yields between infected and non-infected lemon trees are due to long-term, accumulated stress. Other stresses such as poor soil drainage, nutrient deficiency, soil-borne pathogens, salinity and drought can maximize the yield loss during such a long-term. Therefore, citrus yields may (McClure and Schmitt, 1996) or may not develop in the first year following treatment for T. semipenetrans control. Abd-Elgawad et al. (2016) assumed that this yield loss of lemon is due to damage that $T$. semipenetrans has already caused at sampling (February) as fruit set in Egypt always occurs until June. This agrees with the account of Duncan (1989) that citrus yield 5 months only after nematicide use was not influenced by treatment. Sorribas et al. (2008) stated that the impact of nematicides on fruit yield of citrus is shown after the first- (McClure and Schmitt, 1996), second- (Duncan, 1989), or thirdyear applications (Greco et al., 1993). Additionally, this impact ranged from zero to several hundred percent boost in citrus fruits of treated trees though few adverse impacts were also reported. Eventually, citrus yield mostly increases due to nematicide use (Shokoohi and Duncan, 2018).

Tylenchulus semipenetrans influences citrus yields diversely according to the prevailed conditions and locations. Hence, damage threshold values may differ from one location or setting to another. However, they should be joined with related guidelines to assist interpret soil sample data (Duncan, 2009). Consequently, Abd-Elgawad et al. (2016) and Shokoohi and Duncan (2018) stressed that loss assessments for $T$. semipenetrans vary widely between systems and applied functions. In Egypt, the economic thresholds were 13000 and 15000 nematodes per $1 \mathrm{~kg}$ soil and 5 gm roots during low T. semipenetrans population terms in February and August but 36000 nematodes during the peak period in March for Navel orange trees grafted on sour orange rootstock (Korayem and Hasabo, 2005). In another study (Abd-Elgawad et al., 2016), the gain thresholds (the value of harvested lemon that equals the cost of sampling and nematicide application) in Egypt were 6.083 and 4.014 metric tons of lemon feddan ${ }^{-1}\left(=4200 \mathrm{~m}^{-2}\right)$ for cadusafos and oxamyl, respectively. Likewise, the economic thresholds (the population density of T. semipenetrans at which the value of the damage caused is equal to the cost of both sampling and control) were 1810 and 141 second-stage juveniles $\left(150 \mathrm{~cm}^{3} \text { soil }\right)^{-1}$. Incompatible with other differently calculated thresholds (e.g., Ferris 1978; Sorribas et al. 2008), these thresholds utilized the combined costs of $T$. semipenetrans control and sampling to offer an actual assessment of a budget conscious option (Abd-Elgawad et al., 2016). Therefore, predicted citrus yields with probably more sound bases are presented (Table 2).

Stages of $T$. semipenetrans (juveniles/100 g soil) in California below 800 manifested a non-damaging level, but more than 1600 responded favorably to 
nematicide application, and above 3600 treatments may enhance yield substantially (Garabedian et al., 1984). These nematode population densities were reported during the peak growth period of May-July. On the other hand, the nematode females per $g$ root in California with numbers less than 300, more than 700 and more than 1400 manifested low, moderate and high levels, respectively; the threshold level corresponded to 850 juveniles/100 $\mathrm{cm}^{3}$ soil when $T$. semipenetrans population levels were estimated during courses of weak nematode growth.

\section{B. Other Nematode Parasites of Citrus}

Numerous PPN genera and species are also linked to the rhizosphere of citrus trees. However, the nematodes recorded to harm citrus tend to be very limited in distribution and/or to have low population levels. Ordinarily, the following genera (with related species) were reported from citrus orchards: the stubby root nematode Trichodorus (T. teres, T. christie), the lesion nematode Pratylenchus (P. brachyurus, $P$. coffeae, $P$. neglectus, $P$. penetrans, $P$. pratensis, $P$. vulnus, $P$. zeae), the stunt nematode Tylenchorhynchus (T. besselatus, T. brassicae, $T$. clavicaudatus, $T$. latus, $T$. nothus, $T$. phaseoli), the spiral nematode Helicotylenchus (H. dihystera, $H$. hydrophilus, H. microcephalus, $H$. multicinctus, $H$. pseudorobustus), the sheath nematode Hemicycliophora ( $H$. arenaria, $H$. similis), the lance nematode Hoplolaimus ( $H$. columbus, $H$. galeatus, $H$. seshadrii), the needle nematode Longidorus (L. africanus, L. alongates, L. gerogiensis, L. taniwha), the burrowing nematode Radopholus ( $R$. similis, $R$. citri), the dagger nematode Xiphinema ( $X$. imitator, $X$. insigne, $X$. lamberti), and the reniform nematode Rotylenchulus reniformis (Ibrahim, 2006; Abu Habib et al., 2020). For instance, in Egypt PPNs found in the citrus soil and the average percentages of the total nematode community were $T$. semipenetrans (81.2\%), Helicotylenchus pseudorobustus (11.7\%), Criconemella spp. (6.5\%), Pratylenchus brachyurus (0.2\%) and Tylenchorhynchus spp. (0.4\%) in Northern Tahrir Province (Abd-Elgawad, 1992b). Other than T. semipenetrans $(99.1 \%)$, the genera Tylenchorhynchus, Helicotylenchus, Criconemoides, Xiphinema and Pratylenchus accounted for $0.9 \%$ of the total nematode community in citrus groves of El-Nubaria district, El-Behera governorate (Abd-Elgawad et al., 2016). Also, nine PPN genera were recently surveyed in citrus trees at Alexandria, El-Behera and Kafr El-Sheikh governorates, northern Egypt during 2017-2019 growing seasons. Tylenchulus semipentrans was the most common genus (frequency of occurrence $=100 \%$ ) in the surveyed governorates, followed by Trichodorus spp. and Pratylenchus spp. (Abu Habib et al., 2020).

Additional genera such as Meloidogyne (root-knot nematode, RKN) and Longidorus were found in citrus orchards intercropped with tomato in the New Valley governorate (Abd-Elgawad, 2020a). Shokoohi and Duncan (2018) stressed that species related to both migratory endoparasite genera (Radopholus and Pratylenchus) and sedentary endoparasites (Meloidogyne), in addition to species of ectoparasitic nematodes can damage citrus.

Luckily, the most damaging nematode (i.e. the citrus race of Radopholus similis) that brings about the spreading decline disease of citrus trees does not exist in Egypt. However, it is not odd to report the pathogenicity of $R$. citri associated with declining trees in Indonesia (Machon and Bridge 1996). Other common PPN genera/species of citrus groves such as Pratylenchus, Meloidogyne, and Xiphinema were recently addressed in more details (Abd-Elgawad, 2020a). 
Table 1 Precision estimates for Tylenchulus semipenetrans population densities based on data derived from citrus orchards*

\begin{tabular}{lcccc}
\hline $\begin{array}{l}\text { Standard error } \\
\text { to mean ratio } \\
(E)^{* *}\end{array}$ & $\begin{array}{c}1 / 2 \text { confidence } \\
\text { interval to } \\
\text { mean ratio } \\
(D)^{* *}\end{array}$ & $\begin{array}{c}99 \% \\
\text { confidence } \\
\text { interval+ }\end{array}$ & $\begin{array}{c}95 \% \\
\text { confidence } \\
\text { interval++ }\end{array}$ & $\begin{array}{c}80 \% \\
\text { confidence } \\
\text { interval+++ }\end{array}$ \\
\hline \multicolumn{4}{l}{ Taylor's power law parameters: $a=0.83, b=1.95$; in stratified random sampling, Egypt. } \\
\hline 0.17 & 0.35 & $1302-3698$ & $1623-3377$ & $1945-3055 t$ \\
0.17 & 0.33 & $1421-3579$ & $1679-3321$ & $1963-3037 z$ \\
\hline Taylor's power law parameters: $a=1.175, b=1.95 ;$ in systematic sampling, Egypt \\
\hline $20 \%$ & $42 \%$ & $1074-3926$ & $1457-3543$ & $1838-3162 t$ \\
$20 \%$ & $39 \%$ & $1216-3784$ & $1523-3477$ & $1861-3139 z$ \\
\hline Taylor's power law parameters: $a=9.2, b=1.57$; in random sampling, Florida, USA \\
\hline $13 \%$ & $26 \%$ & $1598-3402$ & $1840-3160$ & $2081-2919 t$ \\
$13 \%$ & $25 \%$ & $1688-3312$ & $1882-3118$ & $2095-2904 z$ \\
\hline
\end{tabular}

*Abd-Elgawad (1992a) for citrus in Egypt, and Duncan (1989) for citrus in Florida. Soil sample size of $100 \mathrm{gm}$ in Egypt or $100 \mathrm{~cm} 3$ in Florida.

** $E$ and $D$ values rounded up to nearest two decimals with $D$ at $95 \%$ probability.

${ }^{t}$ and ${ }^{z}$ refer to using Student's $t$ value and standard normal deviate, respectiv

Table 2 Predicted marketable fruit losses in 'banzaheer' lemon (Citrus aurantifolia) at increasing citrus nematode density (Abd-Elgawad et al., 2016).

\begin{tabular}{lllll}
\hline $\begin{array}{l}\text { Nematode } \\
\text { population } \\
\left(\mathrm{J}_{2} / 150 \mathrm{~cm}^{3} \text { soil }\right)\end{array}$ & $\begin{array}{c}\text { Predicted fruit } \\
\text { weight }(\mathrm{kg} / \mathrm{tree})\end{array}$ & $\begin{array}{c}\text { Predicted fruit } \\
\text { loss }(\mathrm{kg} / \text { tree })\end{array}$ & $\begin{array}{c}\text { Fruit loss } \\
\text { (Tons/feddan) }\end{array}$ & $\%$ loss \\
\hline 0 & 126.529 & 0 & 0 & 0 \\
110 & 102.702 & 23.827 & 3.812 & 18.8 \\
500 & 95.027 & 31.502 & 5.040 & 24.9 \\
900 & 92.048 & 34.481 & 5.517 & 27.3 \\
1200 & 90.59 & 35.939 & 5.750 & 28.4 \\
1500 & 89.459 & 37.07 & 5.931 & 29.3 \\
2000 & 88.0 & 38.529 & 6.165 & 30.5 \\
2300 & 87.292 & 39.237 & 6.278 & 31.0 \\
\hline
\end{tabular}

\section{Nematode Management on Citrus in Egypt}

\section{Pre-considerations}

\section{i) Applying Strict PPN Quarantine and Certification Programs}

Quarantine regime that has favorably attained proper protection of citrus trees from PPN pests in Florida (Inserra et al., 2005) should be applied in Egypt. Moreover, both private and governmental sectors should be motivated to realize the requirements of our national certified citrus seedlings. Abd-Elgawad (2020a) stressed that a citrus nursery certification program as preventive measure against PPNs especially $T$. semipenetrans, should be conducted and centered on two steps, i.e. site approval and pre-movement certification of healthy citrus plants before leaving the nursery. Constant monitoring through soil/root sampling of nematodes is also basic to this plan. Isolating nursery locations to avoid runoff water from infested orchards and phytosanitary measures are basics to avoid contamination of planting material and equipment in nursery area and non-infested orchards. All stakeholders in Egypt should address the problem jointly to allocate sufficient money to obtain enough 
locally certified citrus seedlings and prepare related experts to apply strict quarantine actions similar to those of Florida citrus. Healthy citrus-propagating material should also include bacteria, fungi, and other transmissible pathogens (Abd-Elgawad et al., 2016). Abd-Elgawad and McSorley (2009) also proposed a citrus nursery certification program to help overcome the reluctance of nurserymen in Egypt to move the nurseries to sites that can produce nematode-free planting material and to convince growers to refrain from mulching virgin soil with infested soil from the Nile Valley. Their feasibility study of this program concluded that for every L.E. 59,524 invested in a certification project, there would be a return of L.E. one million. Other technically qualified specifications of seedlings (El-Barkoki and Abou-Aziz, 1989) to produce healthy intact-rooted plants along with the above-mentioned phytosanitary measures must be a way forward in citrus protection/pest management in Egypt.

\section{ii) Applying the Limiting Factor Principle}

The limiting factor principle (Thomason and Caswell 1987) points out that tree cannot respond to nematode treatment if PPNs, especially $T$. semipenetrans, are but one among other constraints to good tree growth. In such case(s), the trees damaged by poor drainage, soil borne-pathogens, salinity, frequent drought and/or other problems are unlikely to respond favorably to control of just PPNs. Hence, orchards should be managed properly in all aspects before applying nematode control tactics. Conversely, healthy groves with high $T$. semipenetrans population densities are those in which nematode control is most likely to be gainful. Remarkably, PPNs may occasionally aggravate citrus damage inflicted by other stresses (Mashela and Nthangeni, 2002). Ultimately, a variety of PPN management methods may be included in a conclusive program of assessing all yield-forming and -reducing factors which would signify citrus sustainability evaluation.

\section{iii) Appropriate Nematode Sampling and Extraction}

As PPN sampling and extraction methods are basic to nematode advisory and diagnostic services, their optimization should be a pre-consideration (Abd-Elgawad, 2021b). Proper PPN sampling time and method as well as extraction and processing technique (Abd-Elgawad 2021b; Shokoohi and Duncan, 2018) are basics to detect and identify PPN problems. Nematode threshold numbers or at least the common importance of the detected PPN species should be considered. In Egypt, the economic thresholds of $T$. semipenetrans have been estimated in the Nile valley (Korayem and Hasabo, 2005) and newly reclaimed land (Abd-Elgawad et al. 2016) as well as on different citrus varieties (Abd-Elgawad 1995; Abd-Elgawad et al. 2016). As Radopholus similis is not found in Egypt, treatment for other PPN species is usually only considered when they are found in combination with $T$. semipenetrans in the same field.

\section{Nematicidal Application}

Having assured the limiting factor principle, the need to control T. semipenetrans should be properly sought. Resistant rootstocks, bio/chemical nematicides, or production practices, e.g. solarization and the type of the fertilizer applied are globally practiced control tactics. The Swingle citrumelo is a resistant rootstock. Its use combined with regulation program of $T$. semipenetrans has reduced the nematode spread dramatically in Florida (Lehman, 1996). Even so, resistance-breaking biotypes were developed on Swingle citrumelo there (Duncan et al., 1994). As Swingle citrumelo performs badly in Egyptian alkaline soils and those high in lime, resistant Forner-Alcaide no.5 rootstock is preferable because it tolerates alkaline and 
calcareous soils of Egypt (Abd-Elgawad, 2020a). Shokoohi and Duncan (2018) stressed that the most effective pre-plant nematicides in citrus are fumigants such as metam sodium and 1,3-dichloropropene. The latter fumigant has several commercial products in Egypt such as Telone II or Dorlone II, which are used in citrus nurseries/orchards for their high PPN control efficacy. Since chloropicrin is applied effectively against diseases but seldom nematodes or weeds, 1,3-dichloropropene is also mixed with chloropicrin (Telone $\mathrm{C} 17$ or Telone C35), making it a multi-purpose soil fumigant in Egypt too (Abd-Elgawad, 2008). The product contains either 17\% or $35 \%$ chloropicrin. Telone C35 combined with a separate herbicide for weed management, was reported as the best chemical alternative substituting Methyl bromide (MB) for obtaining effective nematode control and superior strawberry production (Noling, 2016).

Various production practices such as tillage, solarization, and addition of organic and inorganic amendments can contribute in nematode management. Yet, the major related ones are post-plant, non-fumigant nematicides, usually applied in Egypt in February and March with flushing of new fibrous roots (or periods when nematodes actively invade new roots). Major groups of nematicides are oxime-carbamates (aldicarb, oxamyl, carbofuran) and organophosphates (fenamiphos, ethoprophos, and cadusaphos) but granular cadusafos has shown superior efficacy against $T$. semipenetrans (Verdejo-Lucas and McKenry, 2014). Nevertheless, a few such as aldicarb and fenamiphos were deregistered for use in citrus whiles the efficacy and profitability of the other available nematicides vary widely (Shokoohi and Duncan 2018; El-Tanany et al., 2018). For mature citrus trees, Egyptian governmental recommendations include distribution of nematicides such as cadusaphos $10 \%$ granules at rate of $24 \mathrm{~kg} / F e d d a n$ on the soil surface and incorporate it mechanically into the top $10 \mathrm{~cm}$ of soil or spraying oxamyl $24 \%$ liquid on soil surface under tree canopy and on tree shoots at rate of 4 liter per 600 liter water/Feddan twice; 3-4 weeks between them (Anonymous, 2017). For young citrus trees, similar broadcast and incorporation of nematicides such as oxamyl $10 \%$ granules at rate of 25 $\mathrm{kg} /$ Feddan is recommended. For large-scale and commercial orchards, nematicides are applied in bands down the citrus tree rows or through low-volume irrigation systems. In all cases, these nematicides should be incorporated in the soil, either mechanically or with irrigation for efficacy and safety.

New compounds with nematicidal activity and different modes of action are being tested or are at the pipeline for registration (El-Zawahry et al., 2014; El-Saedy et al., 2019; Abd-Elgawad and Askary 2018, 2020). However, systemic nematicides (e.g., oxamyl) are translocated within the tree and suppress both harmful and beneficial species in addition to nematodes (Hammam et al., 2016b; Shokoohi and Duncan, 2018).

Bionematicides rank high among PPN management options given indirect adverse effects of chemical nematicides. Biologicals and natural compounds, as nematicides, are intended to avoid health hazards and set up pollution-free environment. The effects of several plant extracts and organic manure (Montasser et al., 2012a) as well as fungi and bacteria (Montasser et al., 2012b) to control T. semipenetrans on citrus in Egypt were detailed. Moreover, the impacts of EPNs and other biorational compounds on the citrus nematode populations on citrus were similarly evidenced (Abd-Elgawad et al., 2013). With the multiplicity and variety of experiments they are involved in, insecticidal nematodes advance and occupy a suitable position among other biopesticides for T. semipenetrans control as well (e.g., Abd-Elgawad et al., 2013; Abd-Elgawad, 2017a, b). New directions are developing to leverage EPN efficacy with costs-effective techniques comprise optimizing sampling and extraction methods 
(Abd-Elgawad, 2020c; Abd-Elgawad, 2021b), detecting and/or developing enhanced strains, lowering costs of mass production, formulation and application technology, adequate combination with other control tactics (Abd-Elgawad and Askary, 2021), and environmental manipulation (Koppenhöfer et al., 2020; Dritsoulas et al., 2021). For instance, application is eased by a variety of formulations that offer stability and favorable use, e.g. alginate and polyacrylamide gels, vermiculite, clay, paste, activated charcoal, diatomaceous earth, peat, polyurethane sponge, and water dispersible granules. Even EPN suspension that can timely and simply be added to the tank and drip irrigated are most cute given their enhanced efficacy on pest control and seed germination rate (Shehata et al., 2021). Abd-Elgawad (2020b) has recently reviewed the different groups of BCAs to identify conditions and practices that influence their use for nematode management and alternatives to maximize their useful applications against PPNs with various approaches to diminish costs, facilitate availability, optimize application and improve their efficacy. Researchers should further grasp the complex network of interactions among biotic and abiotic factors in intimate contact with these BCAs to maximize their gains via additive or synergistic effects (Abd-Elgawad and Askary, 2018).

\section{IV) Adequate Production Practices for Managing Pests and Pathogens}

Factually, despite this distinguished position of citrus trees in Egypt, more can be done to increase citrus production via proper production practices especially against the related pests and pathogens, as follows: 1) Prophylactic plans should earnestly be used especially for pressures such as arthropod pests, weeds, PPNs, and postharvest diseases. Monitoring should always be on as the intensity of surveillance is correlated to key pests in terms of their emergence times, conditions, and successful management. Certified crop agricultural extensions/advisors may be consulted to identify and review their economic threshold levels and offer consultation on the best citrus protection approaches, if so demanded by the farmer. Also, agricultural practices must include attention to proper ventilation and shape of citrus trees, appropriate pruning, and disposal of the bushes that are secondary shelters for various pests and pathogens. Bearing citrus trees are pruned to keep both rows and trees open for easily harvesting operations and allow maximum light penetration. Planting a single fruit tree species per grove is preferred so that the date of infection can be determined and control measures be implemented in a timely manner (Abd-Elgawad 2021a), 2) It is best to avoid cultivating pome and stone fruit trees within the range of citrus groves so as not to facilitate the transmission of the Medfly, Citrus capitata from one plant species to another, to stop the life cycle of the pest that can reproduce on more than one host. Otherwise, plant traps can be used where susceptible trees to the pest are planted near citrus trees that attract adult flies, such as planting guavas whose fruits are preferred to the insect more than the fruits of citrus varieties, provided that the infected fruits are collected daily and regularly and destroyed, 3) Tillage should be practiced in such a way that exposes the subterranean pest stages, e.g. the pupae of fruit flies, to inadequate environmental conditions such as heat and sunlight as well as their interaction with parasites and predators for killing them. If water is sufficient, submerging the orchard floor with water, will lead to the suffocation and death of these pests. They will also be exposed to the act of certain micro-organisms in the soil, which are activated at such moisture availability, 4) Cultivation of varieties resistant or tolerant to plant pathogens and pests, as well as the use of varieties grafted on rootstocks resistant to a specific pest or a number of citrus pests (Ali et al., 2020). Nevertheless, there must be a continuous need to pay attention 
to regular irrigation, appropriate fertilization, and provision of proper nutrients that would improve the health of the tree, 5) Use of mechanical means for pest control should be carefully practiced. These may include the use of various traps (AbdElgawad, 2021a). For instance, important practices are yellow sticky traps against whiteflies, removing the severely infested branches and leaves by various pests, cutting off juvenile branches near the soil surface or in the centre of the tree that are suitable harbor for the insects' reproduction. The infested fruits must also be collected and buried inside the soil at a depth of at least $30 \mathrm{~cm}$ so that the emerging adults of various pest species cannot reach the surface of the soil, they can also be collected in special sealed bags and exposed to sunlight for killing them and any other pests present in or on the fruits. This procedure also helps to reduce the sources of infection. In nurseries, lighting is used at night to keep citrus leafminer adults away, 6) The use of improved techniques should be followed, sterile male technique especially against $C$. capitata, e.g. via radiation and orange oil (Shelly et al., 2006). Also, mowing row middles may replace chemical weed control on a large percentage of the citrus producing acreage. Such chemicals may be used under the tree canopies to maximize fertilizer and water dispersal and efficiency. In the row middles, vegetative strips are mowed cautiously since vegetation is maintained for a number of reasons, most significantly to serve as refugia for naturally occurring BCAs, 7) The employ of natural enemies against pests and pathogens as Egypt has environmental settings rich in many species of biological control agents (BCAs) such as predators, parasitoids, and entomopathogenic nematodes. These BCAs of the Egyptian fauna proved efficiency in controlling various pests and pathogens of citrus orchards, e.g. mealybugs, scale insects, whiteflies, PPNs, and scarab beetles (Mahmoud,1981; Rakha and El-Naggar, 1993; Tawfik et al., 1996; Metwally et al., 1999; Lamya and Abdalla, 2015; El-Husseini et al., 2018; Abd-Elgawad, 2020b, c). However, the numbers and species of these BCAs and their related pests differ from one orchard to another, according to the production practices followed and their fluctuations to keep the natural balance. Therefore, there is a need to provide some nutritional requirements especially for adults of these BCAs by planting some flowering plants or/and protecting the wild/volunteer plants on the edges of the field or near it. Moreover, environmentally friendly materials of various biological pesticides/materials that are compatible with these BCAs should be used in citrus pest management programs, e.g. pheromones, insect growth regulators, and chemical sterility methods as well as plant growth promoters, plant strengtheners, or soil conditioners. The use of locally mass-produced BCAs especially in case of indigenous ones should be a priority; local BCAs may be less expensive, more adapted, and without significant risk to Egyptian fauna and flora, 8) The legislative terms and regulatory measures that represent important issues should be imposed by the official authorities to oblige the less-educated farmers to follow all prophylactic measures against pests and pathogens of citrus orchards, e.g. using healthy certificated citrus seedlings, applying the topical or partial spray methods as much as possible in order to avoid wasting effort and money, and protection of the natural balance and public health. Emphasis should also be placed on strengthening quarantine procedures and controls that regulate the import and export of citrus fruits and their seedlings. Egyptian quarantine on certifiable pathogens of citrus-propagating material should include not only PPNs but also bacteria, fungi, and other transmissible pests and pathogens (Abd-Elgawad, 2020a), 9) Following proper monitoring methods as well as continuous and regular surveillance systems to adequately manage each pest species should be based on the accurately obtained data, e.g. pheromone traps are used for 
citrus leafminer and fruit flies, colored traps for whitefly, and baits suitable for the existing scarab species. Traps for fruit flies should be attached to trees in the peripheral areas a week before the fruit set. This procedure helps to attract the emerging adults before they are transferred to a new host. The use of traps should achieve the objective of monitoring and/or control, provided that the appropriate trap number is used according to the purpose to be fulfilled. Regular samples should also be taken by a well-trained person(s) from the tree leaves in order to assess the percentage of pest infection and determine the extent of the need to intervene with the available control means, 10) The economic threshold level should be considered as the basis on which the control decision is made. Also, this level varies according to the season and its relation to the growth stage, fruit formation and ripening stage (Abd-Elgawad, 2021a), 11) The use of chemical pesticides should focus on selective and safe ones. They may be used when the pest population density exceeds economic levels only. Partial spraying/killing strips and pheromone traps both employ the socalled attract-and-kill approach with insecticide and bait, respectively (Abd-Elgawad 2021a), 12) All the previous procedures do not exclude the fact that attention should be centered on the provision of balanced growth requirements for citrus trees in order to improve the tree health to be more tolerant to various pests and diseases. The need to adopt environmentally safe methods; e.g. organic fertilization and biopesticides should be emphasized.

Just as we explained what needs to be done, it is necessary to emphasize what must be stopped and/or avoided. Many growers/farmers are averse to risks even those involving tasks that improve production practices and may offer better citrus yield in quantity and/or quality. Strikingly, biological pesticides should occupy a priority over unhealthy but traditionally used chemical pesticides. Meanwhile, impractical regulatory processes and bureaucratic/time-consuming barriers to access to BCAs must be avoided. Inadequate participation and imperfect communication with the growers, public, stakeholders, and politicians of the considerable economic benefits of these biocontrol agents and fragmentation of biocontrol sub-disciplines should be averted. Instead, useful related recommendations for the future that emphasize the need for enhanced communication of economic, environmental and social successes and benefits of biopesticides for insect pests, weeds and plant diseases, targeting political, regulatory, grower/land manager and other stakeholder interests should be stressed (Barratt et al., 2017). Awareness-raising of more farmers, cooperatives, and extensions of various biopesticides should be earnestly attempted via deep and broad training (Abd-Elgawad, 2019). A common factor that links public education and public backing for biological control technology is crucial for maintaining the regulatory, economic, and logistical feasibility of these effective biocontrol methods for pest management (Messing and Brodeur, 2018). Therefore, better outreach efforts should extend to a wider audience to help backing up public and economic support for biocontrol potentials.

In conclusion, citriculture sector has changed remarkably due to biotechnological advances in recent decades. Italy was the leading producer until the 1970s, but Spain is now the leading producer in Europe and Egypt is going up among the new competitors (Jaouad et al., 2020). The control of citrus pests and pathogens relied on the use of chemicals but integrated pest management can improve citrus yields as many pests and pathogens can inflict qualitative and quantitative damage. Moreover, holistic management programs (Barrera, 2020) of citrus orchards in ways that make biopesticides complementary or superior to chemical nematicides should further be 
addressed. However, management of nematodes on citrus in Egypt requires primary considerations; proper nematode sampling and extraction methods, improving PPN quarantine, and developing certification programs and considering the limiting factor principle. Pesticidal use and production practices should consider the related experience gained on pests and pathogen management of citrus orchards in Egypt and worldwide. In this respect, holistic comprehension of their biology and ecology as well as their interactions with other biotic and abiotic factors should be harnessed for better pest management.

\section{ACKNOWLEDEGEMENT}

The authors acknowledge the support in part of this study by the US-Egypt Project cycle 17 (no. 172) entitled "Preparing and evaluating IPM tactics for increasing strawberry and citrus production". This article is derived from the Subject Data funded in part by NAS and USAID, and that any opinions, findings, conclusions, or recommendations expressed in it are those of the authors alone, and do not necessarily reflect the views of STDF, USAID or NAS. The facilities offered by The National Research Centre are appreciated.

\section{REFERENCES}

Abd-Elgawad, M.M. (1992a). Spatial distribution of the phytonematode community in Egyptian citrus groves. Rev. Nématol. 14: 367-373.

Abd-Elgawad, M.M. (1992b). Comparative occurrence of phytonematodes and yield responses of citrus. Zagazig J. Agric. Res.19: 2293-2302.

Abd-Elgawad, M.M. (1995). Estimate of (Naval) orange yield loss in Tylenchulus semipenetrans infested groves. Egypt. J. of Appl. Sci. 10: 6-14.

Abd-Elgawad, M.M.M. (2008). The current status of phytonematode management in Egypt with special reference to applicable nematicides. Egypt. J. Agronematol. 6:33-46.

Abd-Elgawad, M.M.M. (2016). Use of Taylor's power law parameters in nematode sampling. Int. J. Pharm.Tech. Res. 9(12):999-1004

Abd-Elgawad, M.M.M. (2017a). Toxic secretions of Photorhabdus and their efficacy against crop insect pests. In: Abd-Elgawad, M.M.M., Askary, T.H., Coupland, J. (eds); Biocontrol agents: entomopathogenic and slug parasitic nematodes. CAB International: Wallingford, UK, 231-260.

Abd-Elgawad, M.M.M. (2017b). Comments on the economic use of entomopathogenic nematodes against insect pests. Bull. NRC., 41: 66-84.

Abd-Elgawad, M.M.M. (2017c). Accuracy and precision of phytonematode sampling plans. Agric. Eng. Int.: CIGR J., Special issue: 6-15.

Abd-Elgawad, M.M.M. and Askary, T.H. (2018) Fungal and bacterial nematicides in integrated nematode management strategies. Egypt. J. Biol. Pest. Cont. 28:74 https://doi.org/10.1186/s41938-018-0080-x.

Abd-Elgawad, M.M.M. (2019). Towards optimization of entomopathogenic nematodes for more service in the biological control of insect pests. Egypt. J. Biol. Pest. Cont. 29:77 DOI: 10.1186/s41938-019-0181-1.

Abd-Elgawad, M.M.M. (2020a). Managing nematodes in Egyptian citrus orchards. Bull. NRC. 44:41 https://doi.org/10.1186/s42269-020-00298-9.

Abd-Elgawad, M.M.M. (2020b). Plant-parasitic nematodes and their biocontrol agents: current status and future vistas. In: Ansari RA, Rizvi R, Mahmood I (eds) Management of phytonematodes: recent advances and future challenges. Springer Nature Singapore Pte Ltd., Singapore, 171-204. 
Abd-Elgawad, M.M.M. (2020c). Can rational sampling maximize isolation and fix distribution measure of entomopathogenic nematodes. Nematol. 22(8): 907916. doi: https://doi.org/10.1163/15685411-00003350.

Abd-Elgawad, M.M.M. (2021a). The Mediterranean fruit fly (Medfly), Ceratitis capitata (Diptera: Tephritidae), a key pest of citrus in Egypt. J. Integr. Pest Manag., In Press.

Abd-Elgawad, M.M.M. (2021b). Optimizing sampling and extraction methods for plant-parasitic and entomopathogenic nematodes. Plants 10(4), 629. doi: 10.3390/plants10040629.

Abd-Elgawad, M.M.M. and McSorley, R. (2009). Movement of citrus nematodeinfested material onto virgin land: detection, current status and solutions with cost-benefit analysis for Egypt. Egypt. J. Agronematol. 7(1):35-48.

Abd-Elgawad, M.M.M. and Askary, T.H. (2020). Factors affecting success of biological agents used in controlling plant-parasitic nematodes. Egypt J. Biol. Pest. Cont. 30:17 https://doi.org/10.1186/s41938-020-00215-2.

Abd-Elgawad, M.M.M.; Youssef, M.M. and Shamseldean, M.M. (1994). Observations on the population fluctuations of the citrus nematode on Calamondin orange in Egypt. Pakistan. J. Nematol. 12(1):87-94.

Abd-Elgawad, M.M.M.; Abd-El-Khair, H.; Koura, Faika, F.H.; Abd El-Wahab, A.E.; Montasser, S.A. and Hammam, M.M.A. (2013). Comparative effects of entomopathogenic nematodes and other biorational compounds on Tylenchulus semipenetrans Cobb populations on citrus. Egypt. J. Agronematol. 12(1):74-90.

Abd-Elgawad, M.M.M.; Abou-Deif, M.H.; Hammam, M.M.A.; Abd-El-Khair, H.; Koura, Faika, F.H.; Abd El-Wahab, A.E. and Montasser, S.A. (2015). Effect of infection with Tylenchulus semipenetrans on enzymatic activities in citrus. Int. J. Eng. Sci. Innov. Technol. (IJEIT). 4(12):43-48.

Abd-Elgawad, M.M.M.; Koura, Faika, F.H.; Montasser, S.A. and Hammam, M.M.A. (2016). Distribution and losses of Tylenchulus semipenetrans in citrus orchards on reclaimed land in Egypt. Nematol. 18: 1141-1150. https://doi.org/10.1163/15685411-00003020.

Abu Habib, A.H.A.; Younes, H.A.; Ibrahim, I.K.A. and Khalil, A.E. (2020). Plant parasitic nematodes associated with citrus trees and reaction of two citrus cultivars to Tylenchulus semipenetrans in Northern Egypt. J. Adv. Agric. Res.(Fac. Agric. Saba Basha), 25(2):166-175.

Ali, A.S.A.; Fiad, M.A.; Makkouk, K.; Zian, S.A.; Hasanain, M.K.; Al-Jboory, I.; Bayaa, B.; Abo Shal, A.M.; Elnahas, S.E.M.; Abd-Elgawad, M.M.M. and Alyousuf, A.A. (2020). Research challenges in plant protection science (In Arabic). Pp. 387-425. In: Plant Protection Challenges in the Arab Countries: 2050 Vision. K. Makkouk, S.G. Kumari, I. Al-Jboory and B. Bayaa (eds.). Arab Society for Plant Protection, Beirut, Lebanon. 523.

Anonymous (2017). [Adopted recommendations to combat agricultural pests.] Qalioub, Qalioubia, Egypt, Agricultural Pesticide Committee, Ministry of Agriculture, Commercial Al-Ahram Press.

Askary, T.H. and Abd-Elgawad, M.M.M. (2021). Opportunities and challenges of entomopathogenic nematodes as biocontrol agents in their tripartite interactions. Egypt. J. Biol. Pest. Cont. 31:42 https://doi.org/10.1186/s41938021-00391-9. 
Barratt, B.I.P.; Moran, V.C.; Bigler, F. and van Lenteren, J.C. (2017). The status of biological control and recommendations for improving uptake for the future. BioControl 63:155-167. https://doi.org/10.1007/s10526-017-9831-y.

Barrera, J.F. (2020). Holistic Pest Management. In D. Perez-Staples, F. DiazFleischer, P. Montoya, \& M. T. Vera (Eds.), Area-wide management of fruit fly pests (275-293). Boca Raton: CRC Press, Taylor \& Francis Group.

Cohn, E. (1966). Observations on the survival of free-living stages of the citrus nematode. Nematologica. 12:321-327.

Dritsoulas, A.; El-Borai, F.E.; Shehata, I.E.; Hammam, M.M.; El-Ashry, R.M.; Mohamed, M.M.; Abd-Elgawad, M.M. and Duncan, L.W. (2021). Reclaimed desert habitats favor entomopathogenic nematode and microarthropod abundance compared to ancient farmlands in the Nile Basin. J. Nematol. 53, 1-13, DOI: https://doi.org/10.21307/jofnem-2021-047.

Duncan, L.W. (1986). The spatial distribution of citrus feeder roots and of the citrus nematode, Tylenchulus semipenetrans. Rev. Nématol. 9: 233-240.

Duncan, L.W. (1989). Effect of fenamiphos placement on Tylenchulus semipenetrans and yield in a Florida citrus orchard. J. Nematol. 21: 703-706.

Duncan, L.W. (2009). Managing nematodes in citrus orchards. In: Ciancio A, Mukerji $\mathrm{KG}$ (eds) Integrated management of fruit crops and forest nematodes, Springer Science+Business Media B.V., pp 135-173 https: //doi.org/ 10.1007/ 978-1-4020-9858-1.

Duncan, L.W.; Inserra, R.N.; O'Bannon, J.H. and El-Morshedy, M.M. (1994). Reproduction of a Florida population of Tylenchulus semipenetrans on resistant citrus rootstocks. Plant Dis. 78:1067-1071.

El-Barkoki, M.H. and Abou-Aziz, A.B. (1989). [The national programme for improving citrus production.] Cairo, Egypt, Academy of Scientific Research and Technology, Ministry of Agriculture and the National Research Centre.

El-Husseini, M.M.; El-Heneidy, A.H. and Awadallah, K.T. (2018). Natural enemies associated with some economic pests in Egyptian agro-ecosystems. Egypt. J. Biol. Pest. Cont. 28:78 https://doi.org/10.1186/s41938-018-0081-9.

El-Saedy, M.A.M.; Hammad, S.E. and Allah, S.F.A. (2019). Nematicidal effect of abamectin, boron, chitosan, hydrogen peroxide and Bacillus thuringiensis against citrus nematode on Valencia orange trees. J. Plant. Sci. Phytopathology. 3: 111-117.

El-Tanany, M.M.; El-Shahaat, M.S. and Khalil, M.S. (2018). Efficacy of three biopesticides and oxamyl against citrus nematode (Tylenchulus semipenetrans) and on productivity of Washington Navel orange trees. Egypt. J. Hort. 45(2):275-287.

El-Zawahry, A.M.; Mahran, A.M.A. and Sallam, M.A. (2014). Management of citrus nematode (Tylenchulus semipenetrans) by certain plant species. J. Phytopathol. Pest Manag. 1(3): 46-52.

Ennab, H.A. (2016). Effect of humic acid on growth and productivity of Egyptian lime trees (Citrus aurantifolia swingle) under salt stress conditions. J. Agric. Res. Kafr El-Sheikh Univ.42(4):494-505.

Ferris, H. (1978). Nematode economic thresholds: derivation, requirements, and theoretical considerations. J. Nematol.10:341-350.

Garabedian, S.; Van Gundy, S.D.; Mankau, R. and Radewald, J.D. (1984). Nematodes. In: Integrated Pest Management for Citrus. University of California, Riverside, 129-131. 
Greco, N.; Basile, M.; D’Addabbo, T. and Brandosino, A. (1993). Influence of aldicarb and fenamiphos on Tylenchulus semipenetrans population densities and orange yield. J. Nematol. 25:768-772.

Hammam, M.M.A.; El-Nagdi, W.M.A. and Abd-Elgawad, M.M.M. (2016a). Biological and chemical control of the citrus nematode, Tylenchulus semipenetrans (Cobb, 1913) in Egypt. Egypt. J. Biol. Pest. Cont. 26(2):345349.

Ibrahim, I.K.A. (2006). Diseases and pests of vegetable crops and control methods. Monshaat Al-Maarf Publisher, Alexandria, Egypt.

Ibrahim, A.M. and Khaleef, M.N.H. (1997). The citrus: cultivation, care, and production (In Arabic). Monshaat Almaarf, Alexandria, Egypt, 718.

Inserra, R.N.; Stanlet, J.D.; O'Bannon, J.H. and Esser, R.P. (2005). Nematode quarantine and certification programmes implemented in Florida. Nematol. Medit. 33:113-123.

Jaouad, M.; Moinina, A.; Ezrar, S. and Lahlali, R. (2020). Key pests and diseases of citrus trees with emphasis on root rot diseases: An overview. Mor. J. Agri. Sci. 1(3):149-160.

Koppenhöfer, A.M.; Shapiro-Ilan, D.I. and Hiltpold, I. (2020). Entomopathogenic nematodes in sustainable food production. Front Sustain Food Syst 4:125. https://doi.org/10.3389/fsufs.2020.00125.

Korayem, A.M. and Hassabo, S.A.A. (2005). Citrus yield in relation to Tylenchulus semipenetrans in silty loam soil. Int. J. Nematol. 15:179-182.

Lamya, M.Z. and Abdalla, A. (2015). Seasonal abundance of the citrus leaf miner, Phyllocnistis citrella, Stainton (Lepidoptera: Gracillariidae) and its parasitoids in Alexandria, Egypt. Egypt. J. Biol. Pest Control., 25(3), 2015, 597-602. Proceeding of 4th International Conference, ESPCP2015, Cairo Egypt, 19-22 October 2015.

Lehman, P.S. (1996). Role of plant protection organizations in nematode management. XIX Congress of Brazilian Society of Nematology. Rio. Quente. Brazil., 137-148.

Machon, J.E. and Bridge, J. (1996). Radopholus citri n. sp. (Tylenchida: Pratylenchidae) and its pathogenicity on citrus. Fundament. Appl. Nematol. 19:127-133.

Mahmoud, S.F. (1981). Ecological studies on the California red scale and the purple scale insects on citrus trees and effect of some insecticides on them and their parasites. M. Sc. Thesis. Fac. Agric. Cairo. Univ. Egypt.

Mangat, B.P.S. and Sharma, N.K. (1981). Influence of host nutrition on multiplication and development of citrus nematode. Indian Phytopathol.,34:90-91.

Mashela, P.W. and Nthangeni, M.E. (2002). Osmolyte allocation in response to Tylenchulus semipenetrans infection, stem girdling, and root pruning in citrus. J. Nematol.34: 273-277.

McClure, M.A. and Schmitt, M.E. (1996). Control of citrus nematode, Tylenchulus semipenetrans, with cadusafos. J. Nematol. 28:624-628.

Messing, R. and Brodeur, J. (2018). Current challenges to the implementation of classical biological control. BioControl 63:1-9. https ://doi. org/ 10. 1007/ s 10526-017-9862-4.

Metwally, S.M.; El-Heneidy, A.H.; Shenishen, Z.; Boraei, H.A. and Mesbah, A.H. (1999). Clitostethus arcuatus (Rossi) (Coleoptera: Coccenillidae), a predator species, of the citrus whitefly, Dialerodes citri (Ashm.) (Homoptera: Aleyrodidae) in Egypt. Egypt. J. Biol. Pest. Control. 9(2):60-70. 
Montasser, S.A.; Abd El- Wahab, A.E.; Abd-Elgawad, M.M.M.; Abd-El-Khair, H.; Koura, Faika, F.H. and Hammam, M.M.A. (2012a). Role of some plant extracts and organic manure in controlling Tylenchulus semipenetrans Cobb in vitro and in vivo in citrus. J. Appl. Sci. Res., 8(11): 5415-5424.

Montasser, S.A.; Abd El- Wahab, A.E.; Abd-Elgawad, M.M.M.; Abd-El-Khair, H.; Koura, Faika, F.H. and Hammam, M.M.A. (2012b). Effects of some fungi and bacteria as bio-control agents against citrus nematode Tylenchulus semipenetrans Cobb. J. Appl. Sci. Res. 8(11): 5436-5444.

Noling, J.W. (2016). Nematode management in strawberries, University of Florida publication Series no. ENY-031, USA, p 12.

O'Bannon, J.H.; Reynolds, H.W. and Leathers, C.R. (1966). Effects of temperature on penetration, development, and reproduction of Tylenchulus semipenetrans. Nematologica, 12:483-487.

O'Bannon, J.H. and Hutchinson, D.H. (1974). Development of rootstocks resistant to the citrus nematode, Tylenchulus semipenetrans. In: Jackson LK, Krezdorn AH, Soule J (eds) Proceedings of the $1^{\text {st }}$ International Citrus Short Course (Sept. 24-29, 1973). Gainesville, Florida, 22-29.

Omar, S. and Tate, B. (2018). Annual report of citrus. https: //apps. fas. usda. gov/ newgainapi/api/report/downloadreportbyfilename?filename=Citrus\%20Annua 1_Cairo_Egypt_12-10-2018.pdf.

Rakha, M.A. and El-Naggar, M.E. (1993). Predaceous mite populations in relation to citrus pests in Egypt. Egypt. J. Biol. Pest. Control. 3(1):21-28.

Raza, M.F.; Yao, Z.; Dong, X.; Cai, Z. and Zhang, H. (2017). Citrus insect pests and their non chemical control in China. Citrus Res. Technol. 38(1): http://dx.doi.org/10.4322/crt.ICC117

Safdar, A.; Javed, N.; Khan, S.A.; Safdar, H.; Haq, I.U.; Abbas, H. and Ullah, Z. (2013). Synergistic effect of a fungus, Fusarium semitectum, and a nematode, Tylenchulus semipenetrans, on citrus decline. Pakist. J. Zool. 45(3):643-651.

Salem, A.A.M. (1980). Observations on the population dynamics of the citrus nematode, Tylenchulus semipenetrans in Sharkia Governorate. Egypt. J. Phytopathol.12:31-34.

Shehata, I.E., Hammam, M.M.A. and Abd-Elgawad, M.M.M. (2021). Effects of inorganic fertilizers on virulence of the entomopathogenic nematode Steinernema glaseri and peanut germination under field conditions. Agronomy 11, 945. https://doi.org/10.3390/agronomy11050945.

Shelly, T.E.; Edu, J. and Pahio, E. (2006). Application of orange oil to pre-release holding boxes increases the mating success of sterile males of the Mediterranean fruit fly in field cage trials (Diptera: Tephritidae). Proc. Hawaiian. Entomol. Soc. 38: 73-79.

Shokoohi, E. and Duncan, L.W. (2018). Nematode parasites of citrus. In:. Sikora R, Timper P, Coyne D (eds) Plant-parasitic nematodes in tropical \& subtropical agriculture, 3rd Edition. CAB International, St. Albans, UK, pp 446-476.

Sorribas, F.J.; Verdejo-Lucas, S.; Forner, J.B.; Alcaide, A.; Pons, J. and Ornat, C. (2000). Seasonality of Tylenchulus semipenetrans Cobb and Pasteuria sp. in citrus orchards in Spain. Supplement to J. Nematol, 32(4S):622-632.

Sorribas, F.J.; Verdejo-Lucas, S.; Pastor, J,; Ornat, C.; Pons, J. and Valero, J. (2008). Population densities of Tylenchulus semipenetrans related to physicochemical properties of soil and yield of clementine mandarin in Spain. Pl Disease. 92:445-450. 
Tawfik, M.F.S.; El-Dakroury, M.S.I.; Afifi, Amal, I.; Ibrahim, A.M. and Eid, F.M.H. (1996). Parasitic species secured from larvae and pupae of the citrus leaf miner, Phylocnistis citrella Stainton, in Egypt (Phyllocnistidae: Lepidoptera). Egypt. J. Biol. Pest. Control. 6(1): 111.

Thomason, I.J. and Caswell, E.P. (1987). Principles of nematode control. In: Brown RH, Kerry BR (eds) Principles and Practice of Nematode Control in Crops. Academic Press, Australia. 87-130.

Timmer, L.W. (1977). Control of citrus nematode Tylenchulus semipenetrans on finetextured soil with DBCP and oxamyl. J. Nematol. 9:45-50.

Tsai, B.Y.; Van Gundy, S.D. (1988). Comparison of anhydrobiotic ability of the citrus nematode with other plant parasitic nematodes. Proc. Int. Soc. Citricult., 2: 983-992.

Verdejo-Lucas, S. and McKenry, M.V. (2014). Management of the citrus nematode, Tylenchulus semipenetrans. J. Nematol.36(4):424-432.

Wally, A. and Akingbe, O.O. (2020). Citrus Annual: Egypt maintains its position as the world leading orange exporter. Report No. EG2020-0061, USDA Foreign Agric. Serv., 7 p. http://citrusbr.com/wp-content/uploads/2021/03/CitrusAnnual_Cairo_Egypt_12-15-2020.pdf.

Wheaton, T.A.; Childers, C.C.; Timmer, L.W.; Duncan, L.W. and Nikdel, S. (1985). Effects of aldicarb on yield, fruit quality, and tree condition on Florida citrus. Proc Florida State Hort. Soc. 98:6-10. 
الملخص العربى

\section{إدارة الآفات ومسبيات الأمراض التي تؤثر على إنتاج الموالح في مصر مع التركيز بشكل خاص على النيماتودا}

مصطفي محمد عطية همام1 ـ محفوظ محمد مصطفى عبد الجواد1 - ويبين روان 2 ــ أحمد البحراوي3

$$
\begin{aligned}
& \text { 1قسم أمر اض النبات ـ المركز القومى للبحوث ـ الدقى } 12622 \text { ـ القاهرة ـ مصر. }
\end{aligned}
$$

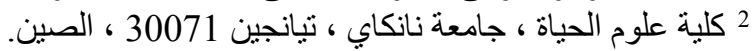

$$
\begin{aligned}
& 3 \text { معهذ الوقاية المستدامة للنبات ـ المجلس القومي للبحوث ـ مدينة باري - ايطاليا. }
\end{aligned}
$$

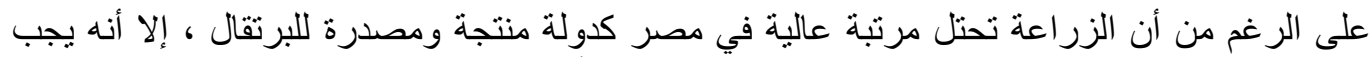

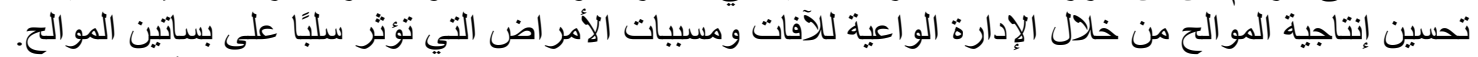

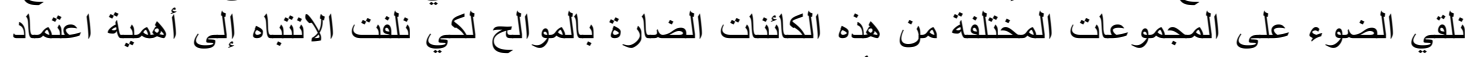

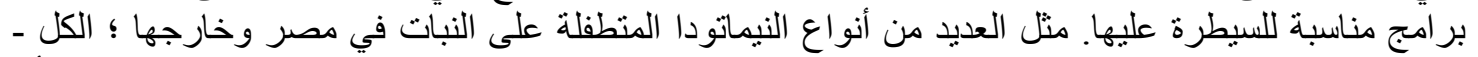

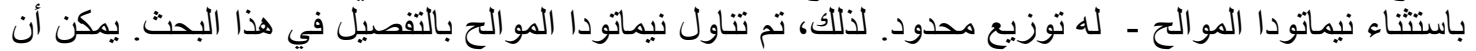

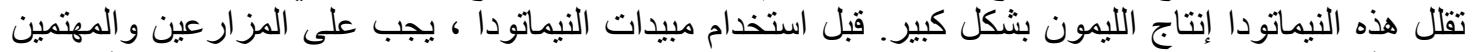

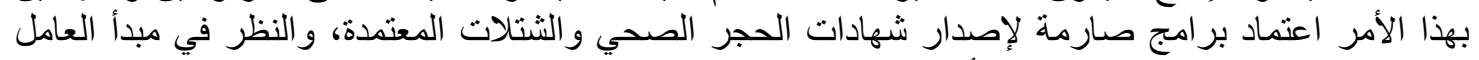

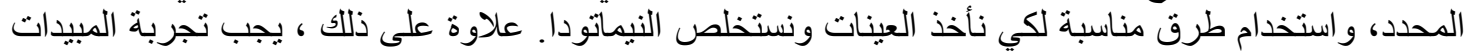

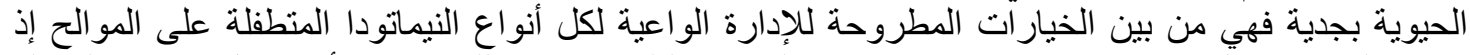

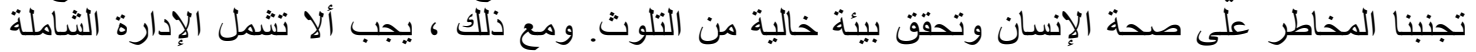

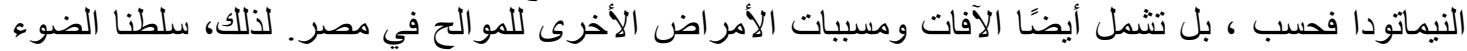

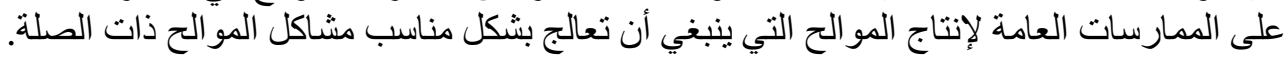

الكلمات الدالة: آفات ومسببات أمر اض المو الح ـ إدارة النيمانودا ـ ممارسات الإنتاج ـ خسارة المحصول. 